\title{
Reproductive and productive performances of Kosali cattle in its native environment
}

\author{
Asit Jain, Deepti K Barwa, Mohan Singh, Kishore Mukherjee, Tripti Jain, MS Tantia, KN Rajam and Arjava Sharma
}

Received: 01 November 2018 / Accepted: 01 January 2019 / Published online: 18 April 2019

(c) Indian Dairy Association (India) 2019

\begin{abstract}
Present study was conducted to record reproductive and productive performances of Kosali cattle maintained under farmer's management conditions in Central Plain Region of Chhattisgarh state. 345 livestock owners were randomly selected and interviewed with structured questionnaire to obtain information on reproductive performance of Kosali cattle. Average age at first calving, calving interval, service period and number of services per conception were found $54.64 \pm 2.18$ months, $430.26 \pm 6.33$ days, $159.59 \pm 2.67$ days and $1.4 \pm 0.08$, respectively. In male, age at first ejaculation and age at first mating were found to be $41.54 \pm 1.14$ and $51.3 \pm 1.05$ months, respectively. Production was recorded and average daily milk yield, peak yield, lactation milk yield, lactation length and dry period were estimated to be $0.92 \pm 0.23 \mathrm{~kg}, 1.27 \pm 0.15 \mathrm{~kg}, 210.3 \pm 4.19 \mathrm{~kg}, 230.7 \pm 9.11$ days and $190.8 \pm 8.19$ days, respectively. Average fat and SNF percent were $4.4 \pm 0.27$ and $10.41 \pm 0.21 \%$, respectively. Observed indices showed poor performances which are below the national average. Hence, suitable breeding strategies and training for livestock keepers and farmers on managemental aspects of Kosali cattle is needed to improve production and reproduction performances.
\end{abstract}

Keywords: Productive and reproductive performances, Kosali cattle, Central Plain region, Chhattisgarh

\section{Introduction}

Indian breeds of cattle have evolved as a result of very long period of natural selection and are well adapted to the existing agro-climatic conditions of the region. They are well known for their disease resistance, heat tolerance, adaptability and can live under the available feed stuffs and low management level. Productive and reproductive traits are crucial factors determining the profitability of dairy production. The reproductive efficiency can be assessed by several parameters which are termed as reproductive indices. Dairy production needs to be monitored regularly by assessing the productive and reproductive performance under the existing management system for improvement (Lobago et al., 2007).

Kosali is the first breed of cattle from Chhattisgarh state registered as the $36^{\text {th }}$ breed of cattle and it is mainly distributed in Central Plain Region of the state. In general, these animals are small sized, draft purpose breed, possessing red coat colour, stumpy horn, horizontal ear (Jain et al., 2017, 2018a,b). These animals are contributing to the work power needed for various agricultural operations. Performance records of Kosali cows will be helpful in designing breeding as well as managemental strategies to develop the dairy sector of the state. However, information on the performance of Kosali cows at rural management systems is very scanty. Therefore, the aim of the present study was to record baseline information and knowledge on productive and reproductive performances of Kosali cattle under rural management conditions in its breeding tract.

\footnotetext{
Asit Jain ( $\square)$

Department of Animal Genetics and Breeding, College of Veterinary Science and Animal Husbandry, CGKV, Anjora, Durg, Chhattisgarh, India Telephone: +917587815942

Email: vetasit@gmail.com

Deepti Kiran Barwa

Department of Animal Genetics and Breeding, College of Veterinary

Science and A. H, CGKV, Anjora, Durg, Chhattisgarh, India

Email: deeptikiran03@gmail.com

Mohan Singh, K Mukherjee

Department of Animal Genetics and Breeding, College of Veterinary

Science and AH, CGKV, Anjora, Durg, Chhattisgarh, India

Email: dr_msingh8@yahoo.co.in
}

\author{
Tripti Jain \\ Animal Biotechnology Centre, CGKV, Durg, Chhattisgarh, India \\ Email: vettripti@gmail.com \\ MS Tantia, KN Raja, Arjava Sharma \\ ICAR-NBAGR, 139, Sector 13, Urban estate, Karnal, Haryana, India
}




\section{Materials and methods Study area and method of data collection}

From the breeding tract of Kosali, three districts, vizRajnandgoan, Baloda bazaar and Bilaspur were selected. In each district, four blocks and in each block, five to seven villages were selected at random by stratified two stage random sample technique. Data on reproduction parameters were collected in structured questionnaires by interviews and group discussion and production was recorded systematically.

345 livestock keepers/farmers were interviewed randomly with scheduled questionnaire. A total of 805 Kosali cows for age at first estrous (months), estrous cycle (days), estrous duration (h), age at first mating (months), and 695 cows for age at first calving (months), service period (days), number of services /conception, calving interval (days), gestation length (days) and number of calving were included. Data were recorded on daily milk yield $(\mathrm{kg})$, peak milk yield $(\mathrm{kg})$, days to reach peak yield, lactation length (days) and dry period (days) in 502 Kosali cows. Milk composition in 72 Kosali cows was recorded. 103 bulls were studied for their sexual behaviour.

\section{Data management and analysis}

Data collected from the field and secondary sources were entered in to database using Excel 2007 software. The data were subjected to statistical analyses as per Snedecor and Cochran (1989) and the results obtained were presented as mean and standard error.

\section{Results and discussion}

\section{Reproductive traits in female}

Age of sexual maturity, oestrous cycle and oestrus duration
Average age of first estrus, average age of sexual maturity, estrus cycle duration and estrus time were $34.15 \pm 0.73$ months, $41.15 \pm 3.27$ months, $21.69 \pm 0.28$ days and $14.45 \pm 0.27 \mathrm{~h}$, respectively. A considerable delay in the attainment of puberty and sexual maturity may mean a serious economic loss, due to an additional, non- lactating, unproductive period of the cow over several months (Mukasa-Mugerewa 1989). At field level, the general trend was observed that livestock owners are not keen to record estrus duration, as they prefer natural breeding.

\section{Age at first fertile mating (AFFM) and calving (AFC)}

Age at first calving is an important trait for economic milk production. Average AFFM and AFC are shown in table 1. These are comparable with Khariar cattle (Dhal et al., 2007). Mean AFC of Manipur and Mizoram (Pundir et al., 2015a, Pundir et al., 2015b), Malnad Gidda (Singh et al., 2008), Bachure (Chandran et al., 2014) cattle were lesser than the mean AFC of Kosali cattle. Different factors advance or delay AFC. Environmental factors, especially balanced nutrition, determine pre-pubertal growth rates, reproductive organ development, and onset of puberty and subsequent fertility. In Chhattisgarh state, farmers provide poor feed stuffs and low management level to Kosali cows. This may be one of the cause of prolonged age of first calving. Therefore, there is need to improve this trait at the farmer's herd.

\section{Gestation period}

Normal gestation period was noticed in Kosali cows in the field conditions, which is in agreement with the gestation period of cattle species.

\section{Service period (SP)}

Under field conditions, service period obtained is shown in table 1, which is comparable to Manipuri and Mizoram (Pundir et al.,

Table 1 Average reproduction traits of female and male in Kosali cattle

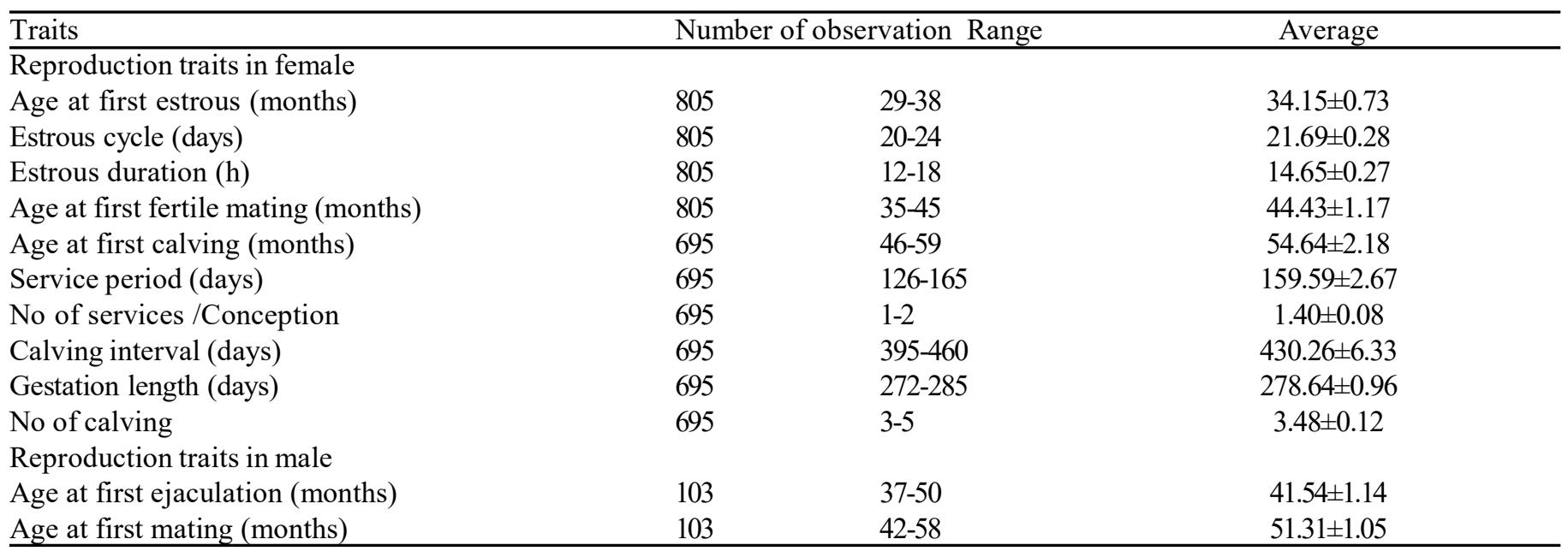


Table 2 Overall mean of production traits in Kosali cows

\begin{tabular}{|c|c|c|c|c|c|c|}
\hline \multirow[t]{2}{*}{ Traits } & \multicolumn{2}{|c|}{ First Lactation } & \multicolumn{3}{|c|}{ Overall } & \multirow[b]{2}{*}{$\mathrm{N}$} \\
\hline & Average & Range & $\mathrm{N}$ & Average & Range & \\
\hline$\overline{\text { Daily milk yield (kg) }}$ & $0.70 \pm 0.17$ & $0.5-0.9$ & 71 & $0.92 \pm 0.23$ & $0.6-1.4$ & 502 \\
\hline Peak milk yield $(\mathrm{kg})$ & $0.90 \pm 0.21$ & $0.8-1.1$ & 71 & $1.27 \pm 0.15$ & $0.9-1.4$ & 502 \\
\hline Days to reach peak yield & $35.0 \pm 3.13$ & $30-45$ & 71 & $38.5 \pm 2.89$ & $30-45$ & 502 \\
\hline Lactation length (days) & $190.3 \pm 10.33$ & $170-240$ & 71 & $230.7 \pm 9.11$ & $180-245$ & 502 \\
\hline Lactation milk yield (kg) & $180.6 \pm 5.19$ & $180-220$ & 71 & $210.3 \pm 4.19$ & $180-220$ & 502 \\
\hline Protein & $3.73 \pm 0.89$ & $3.5-3.94$ & 23 & $3.82 \pm 0.76$ & $3.5-3.94$ & 72 \\
\hline Lactose & $5.81 \pm 0.34$ & $5.5-5.9$ & 23 & $5.2 \pm 0.31$ & $5.5-5.9$ & 72 \\
\hline Dry period (days) & $175.6 \pm 9.12$ & $150-185$ & 91 & $190.8 \pm 8.19$ & $160-200$ & 502 \\
\hline
\end{tabular}

2015a, Pundir et al., 2015b) and Sanchori cattle (Singh et al., 2015) and less than the Malnad Gidda (Singh et al., 2008). The variation in SP reported by different workers may be due to variation in the management efficiency like availability of feed and fodder, estrus detection, silent heat and timely breeding followed in different herds (Savaliya et al., 2016). Service period has its impact on inter calving period and subsequently, on the economics of the milk production. It is needed that the animal should conceive after calving at the earliest. This can be achieved by providing better management and feeding and creating awareness among the owners of the Kosali cattle.

\section{Number of services/mating per conception and number of calving}

Mean number of mating per conception and number of calving are shown in table 1 and these are comparable to Bachaur (Chandran et al., 2014) cattle.

\section{Calving Interval (CI)}

The calving interval ranged and pooled average are shown in table 1 which is comparable to Bachaur (Chandran et al., 2014) and Sanchori (Singh et al., 2015) cattle and less than the Manipuri and Mizoram (Pundir et al., 2015a, Pundir et al., 2015b), Khariar (Dhal et al., 2007) and Malnad Gidda (Singh et al., 2008) cattle. It is more, profitable to have one calf yearly in cattle. If the CI is longer, the total number of calvings in life time and lifetime milk production decreases. Calving interval is affected by age and breed of cows, season of calving and availability of feed and fodder in any particular year (Yifat et al., 2012).

\section{Male reproductive traits}

Age at first ejaculation and age at first mating were found as $41.54 \pm 1.14$ and $51.3 \pm 1.05$ months, respectively (table 1).

\section{Production performance}

\section{Lactation milk yield}

Average daily milk yield and peak yield of Kosali cows are shown in table 2. Days to reach at peak level ranged between 30-45 days. Mean lactation yield was $210.3 \pm 4.19 \mathrm{~kg}$ with a range of $180-220 \mathrm{~kg}$. These production parameters of Kosali cows are comparable with Malnad Gidda (Hegde et al., 1978, Singh et al., 2008) and are lesser than Bachaur (Chandran et al., 2014), Sanchori (Singh et al., 2015), Manipuri and Mizoram (Pundir et al., 2015a, Pundir et al., 2015b) and Vechur (Iype 1996) cattle. Milk production of Kosali cows is lesser than the national average of Indigenous cows. Genetic group, herd size, season of calving and parity has significant effect on lactation milk yield (Kumar et al., 2014).

\section{Lactation Length and dry period}

Average of lactation length and dry period were $230.7 \pm 9.11$ and $190.8 \pm 8.19$ days, respectively, under rural management conditions in the breeding tract (Table 2). This is comparable with Malnad Gidda (Singh et al., 2008), Manipuri and Mizoram (Pundir et al., 2015a, Pundir et al., 2015b) cattle and it is lesser than Sanchori (Singh et al., 2015) cattle.

\section{Composition of milk}

Major contents of milk like percentage of the fat, SNF, lactose, protein etc are shown in the Table 2. This is corresponding to other Indian breeds of cattle. Under the rural conditions, the milking is done twice a day, between 6:30 - 8:00 A.M. in the morning and between 6:30 - 8:00 P.M. in the evening. Weaning is not practiced in the entire breeding tract apparently to ensure milk let down by suckling. Suckling also takes place after milking. Generally milking is done by the thumb pressure or knuckling method rather than full hand milking because of small teats.

\section{Conclusions}

Dairy sector of the studied area is characterized by poor productive and reproductive potential of Kosali cows. None of the farmers surveyed kept records and they exhibit a limited knowledge of improved management. This calls for a planned technical and breeding programmes and intervention of state or 
central Government for improving the Kosali cattle in its native tract. Moreover, in line with this, sustainable extension services, animal feed resources, management and health services are also needed. Breeding plan needs to be adopted wherein better cows may be identified and their male progeny is reared under intensive management to serve as future sires. State animal husbandry department needs to take proactive action for improvement of dairy sector.

\section{Acknowledgements}

The authors gratefully acknowledge the financial assistance rendered by the Indian Council of Agricultural Research-National Bureau of Animal Genetic Resources (ICAR-NBAGR), Karnal, Haryana to carry out the study.

\section{References}

Chandran P, Dey A, Barari S, Kamal R, Bhatt B, Prasad R (2014) Characteristics and performance of Bachaur cattle in the Gangetic plains of North Bihar. Indian Journal of Animal Sciences 84: 87275

Dhal BK, Patro BN, Rao PK, Panda P (2007) Khariar cattle an indigenous germplasm of Nuapada in the undivided Kalahandi district of Orissa. Indian Journal of Animal Sciences 77: 889-93

Hegde BP, Rai AV and Goni SK (1978) Studies on production parameters of Malnad Gidda cattle. Indian Veterinary Journal 55: 870-73

Iype S (1996) The Vechur cattle of Kerala. Animal Genetic Resources Information. FAD, Rome, 18: 61-65

Jain A, Barwa DK, Jain T, Singh M, Mukherjee K, Gendley MK (2017) Estimation of draught ability and related physiological changes in Kosali bullocks in their native place. International Journal of Advanced Biological Research 7 (4):772-774

Jain A, Barwa DK, Singh M, Mukherjee K, Jain T, Tantia M S, Raja KN, Sharma A (2018a) Physical characteristics of Kosali breed of cattle in its native tract. Indian Journal of Animal Sciences 88 (12):136265

Jain A, Barwa DK, Jain T, Singh M, Mukherjee K, Gendley MK (2018b) Geographical distribution, management practices and utility of Kosali cattle at native tract. International Journal of Science, Environment and Technology 6 (6): 3420-26

Kumar N, Yemane A, Berihu G and Desalew TT (2014) Production performance of dairy cows under farmer's management in and around mekelle, Ethiopia. Global Veterinaria 12 (2): 207-212

Lobago F, Bekana M, Gustafsson H, Kindahl H (2007) Longitudinal observation on reproductive and lactation performances of smallholder crossbred dairy cattle in Fitche, Oromia region, central Ethiopia. Tropical Animal Health Production 39: 395-403

Mukasa-mugerewa E (1989) A review of reproductive performance of female Bos indicus (Zebu) cattle, International Livestock Centre for Africa (ILCA), monograph, Addis Ababa, Ethiopia

Pundir RK, Singh PK, Sadana DK, Dangi PS, Lalhruaipuii, Vanlalpeka K, Laldinthara F, Singh NM and Andrew L (2015a) Characterisation of Mizoram native cattle of Indian origin. Journal of Animal Research 5: 801-06

Pundir R, Singh P, Dangi P, Kumar A, Singh N, Singh P, Sadana D (2015b) Indigenous cattle of Manipur- Characterization and performance evaluation. Indian Journal of Animal Sciences 85:382-85

Savaliya BD, Parikh SS, Gamit PM, Gajbhiye PA (2016) Environmental factors affecting economic traits in Gir cattle. International Journal of Science, Environment and Technology 5 (4): 2467-75

Singh PK, Pundir RK, Manjunath VK, Rudresh BH, Govindaiah MG (2008) Features and status of miniature indigenous germplasm of cattle Malnad Gidda. Indian Journal of Animal Sciences 78: 1123-30

Singh PK, Pundir RK and Sadana DK (2015) Features and performance of unexplored Sanchori cattle population of Rajasthan state. Indian Journal of Animal Sciences 85 (8): 923-26

Snedecor GW and Cochran W G (1989) Statistical Methods. $8^{\text {th }}$ Edn. Iowa State University Press.

Yifat D, Bahilibi W and Desie S (2012) Reproductive Performance of Boran Cows at Tatesa cattle breeding center. Advances in Biological Research 6 (3): 101-05 